\title{
Glucose transporters in the brain
}

\author{
BY D. V. RAYNER \\ Division of Biochemical Sciences, Rowett Research Institute, Greenburn Road, Bucksburn, \\ Aberdeen $A B 29 S B$
}

\section{Les transporteurs du glucose dans le cerveau}

\begin{abstract}
RÉSUMÉ
Tous les tissus possèdent une ou plusieurs familles de transporteurs facilitants du glucose (GLUT). Les transporteurs du glucose sont particulièrement importants dans le cerveau car la barrière entre le sang et le cerveau est imperméable à des molécules polaires telles que les glucose, et pourtant cet organe requiert des quantités importantes de glucose qui est sa principale source d'énergie. Le transport facilité du glucose dans le cerveau n'est pas dépendant de l'insuline et implique principalement deux isoformes de transporteurs GLUT1 et GLUT3. GLUT1 se trouve dans les membranes luminale et abluminale de l'endothélium capillaire (c'est-à-dire à la barrière entre le sang et le cerveau). Il se trouve également à un moindre niveau de glycosylation dans le parenchyme du cerveau, où il est le transporteur du glucose des cellules gliales. GLUT3 se trouve essentiellement dans les neurones. Les hautes affinites pour le glucose de GLUT1 et GLUT3 assurent un apport adéquat de glucose aux neurones et minimisent les effets des modifications de la concentration du glucose. La répartition des transporteurs du glucose est modifiée dans le cerveau en développement. Au début de la gestation, avant la fermeture de la barrière entre le sang et le cerveau, GLUT1 est présent dans tout le neuropil; plus tard dans la gestation on trouve GLUT1 en majeure partie dans les vaisseaux sanguins. Après la naissance, GLUT1 est régulé à la baisse avant le sevrage, où le cerveau dépend moins du glucose comme source d'énergie. GLUT3 augmente progressivement après la naissance tandis que s'effectue la maturation des neurones. Les transporteurs du glucose répondent aux demandes nutritionnelles et métaboliques telle que le froid ou le jeûne pour maintenir l'apport de glucose. On ne sait pas bien comment GLUT1 est régulé, mais il semble probable que le degré de glycosylation et le nombre de molécules de transport du glucose sur la membrane des cellules jouent un rôle dans cette régulation. Les niveaux des transporteurs du glucose dans le cerveau sont modifiés dans la maladie. Dans la maladie d'Alzheimer, qui implique la destruction dégénérative des cellules du cerveau et une diminution du métabolisme du glucose, les transporteurs du glucose diminuent en général. Dans les tumeurs du cerveau on voit l'augmentation du métabolisme du glucose, mais aussi une plus grande perméabilité de la barrière entre le sang et le cerveau; GLUT1 est parfois, mais pas toujours, absent, et peut être un marqueur de développement d'une tumeur. Enfin, on a avancé que les transporteurs du glucose feraient partie des mécanismes de sensibilité au glucose dans le cerveau. Il se peut qu'une répartition discrète dan les régions du cerveau connues pour être sensibles au glucose marquent leur implication et expliquent le rôle du cerveau dans la régulation du métabolisme. Le transporteur sensible à l'insuline, GLUT4 a été retrouvé dans l'hypothalamus et le cervelet, tandis que GLUT2 (transporteur à faible affinité du foie et du pancréas) a été
\end{abstract}


retrouvé dans l'hypothalamus et le noyau moteur du vague. On en conclut que la répartition et l'expression des transporteurs du glucose dans le cerveau varie selon le niveau du développement, l'état nutritionnel et avec les maladies. Les facteurs qui déterminent cette régulation ne sont pas encore clairs, mais ont une certaine importance.

For many years it has been evident that the brain requires glucose for its metabolism and that a saturable carrier is involved in the transport of glucose across the blood-brain barrier. However, carrier-mediated glucose transport is more complex than previously thought and is brought about by a multi-gene family of facilitative transporter proteins showing many similarities. One or more of these transporters is expressed in every tissue (for review, see Baldwin, 1993). The facilitative glucose transporters can move glucose only according to its concentration gradient, and are to be distinguished from the Na-dependent glucose transporters, expressed in the epithelia of the kidney and intestine, which can transport glucose against its concentration gradient. Glucose transport in the brain is Na-independent, although there has recently been one report of Na-dependent glucose transport in bovine cortical vessels and rabbit brain (Nishizaki et al. 1995). The present paper reviews the distribution of the facilitative glucose transporters in the brain and their response to nutritional and metabolic challenge.

\section{BRAIN METABOLISM}

Normally the brain utilizes glucose as its key fuel. In the adult human brain, glucose metabolism is about $30 \mu \mathrm{mol} / 100 \mathrm{~g}$ per min; the $\mathrm{O}_{2}$ consumption is approximately equivalent to the glucose utilization and the RQ is, therefore, 1 (Sokoloff, 1973). The adult human subject uses about $110 \mathrm{~g}$ glucose each day for brain metabolism. Indeed, in the resting state, approximately $20 \%$ of whole-body glucose utilization provides fuel for the substantial energy requirements of the brain. The brain is unable to metabolize fat, but can utilize ketone bodies under conditions where their normally low concentrations are raised, such as during a prolonged fast and in the young animal pre-weaning (Sokoloff, 1973).

\section{THE BLOOD-BRAIN BARRIER}

The brain is relatively impermeable to the penetration of polar molecules, such as glucose, from the circulation and carrier-mediated transport of glucose (stereospecific, saturable and insulin-independent; Pardridge \& Oldendorf, 1975; Lund-Andersen, 1979) across the blood-brain barrier has long been recognized. The barrier is located at the endothelial cells of the blood vessels and not at the end feet of the astrocytes which envelop the capillaries (Dermietzel \& Krause, 1991). Unlike other cells (e.g. intestinal epithelia), substances such as glucose cannot diffuse down their concentration gradient through the interstitial spaces between cells, as endothelial cells possess tight junctions that make them impermeable. Tight junctions seem to be induced by the astrocytes. The maturation of the blood-brain barrier is of importance in understanding the changes in glucose-transporter distribution and expression occurring during gestation. Most of the blood vessels in the brain have tight junctions, apart from those in the circumventricular organs, where the blood-brain barrier is absent. 


\section{GLUCOSE TRANSPORT IN THE BRAIN}

The glucose transporter of cerebral microvessels was initially characterized as a protein with a $\mathrm{M}_{\mathrm{r}}$ of 53000 , able to react with antibody to the glucose transporter of erythrocytes (Dick et al. 1984). Using antibodies to the erythroid transporter, glucose transporters were identified by immunocytochemistry in the blood vessels in bovine, rat and human brains (Kasanicki et al. 1987, 1989; Bagley et al. 1989). The isolation of a cDNA clone from rat brain (Birnbaum et al. 1986), which was similar to that for the erythroid glucose transporter, enabled the study of glucose transporters at the level of gene expression by Northern blotting and in situ hybridization. It also allowed the raising of antibodies to the carboxyl terminal sequence of the protein for use in immunocytochemistry and Western blotting. It became evident that, while the $2.8 \mathrm{~kb}$ transcript of the mRNA for this transporter (now termed GLUT1) was expressed strongly in rat and bovine brain (Flier et al. 1987), it could not account for glucose transport in all tissues. The liver, pancreas and small intestine were subsequently found to express a low-affinity transporter, GLUT2 (Thorens et al. 1988), while transcripts of GLUT3 mRNA were expressed in many tissues in the human subject, but in greatest abundance in the brain (Kayano et al. 1988). An insulin-sensitive transporter was found to be present in heart, skeletal muscle and adipose tissue, but not in the brain and other organs (James et al. 1989).

\section{DISTRIBUTION OF GLUCOSE TRANSPORTERS IN THE BRAIN}

GLUT1 is indisputably the glucose transporter of the endothelial cells and, hence, of the blood-brain barrier. By Western blotting, this transporter has been shown to be abundant in the brain and increased in microvessel-rich fractions. The amount of GLUT1 in the microvessel membranes is sufficient to account for its total cytochalasinbinding capacity (Pardridge et al. 1990a). Immunocytochemical studies show staining for this protein in the endothelial cells with little in the brain parenchyma, suggesting that GLUT1 might be found only in the endothelial cells of the blood-brain barrier (Farrell \& Pardridge, 1991). GLUT1 mRNA was not detected in neurons or glia by in situ hybridization (Pardridge et al. 1990a) or Northern blotting of capillary-depleted brain (Boado \& Pardridge, 1990; Dwyer \& Pardridge, 1993). GLUT1, migrating with a $\mathrm{M}_{\mathrm{r}}$ of 47000 (Pardridge et al. 1990a), however, was found in this capillary-depleted synaptosomal preparation. Because of their failure to demonstrate GLUT1 mRNA in the brain parenchyma, this group has suggested that neuronal or glial GLUT1 is synthesized in the endothelium and secreted from its ablumenal membrane for incorporation in the neuropil (Pardridge \& Boado, 1993). The GLUT1 in the lower glycosylation state most probably originates from the glial cells, although possibly from the neurons (Maher et al. 1994), but confirmation of this has been hampered by the difficulty in detecting glial GLUT1 by immunocytochemistry or in situ hybridization (Simpson et al. 1994b). However, GLUT1 mRNA progressively increases from birth to maturity in brain parenchymal cells which are characteristic of astrocytes in the rat (Bondy et al. 1992); GLUT1 has now been positively identified in astrocytes in grey but not white matter (Morgello et al. 1995). It now seems evident that GLUT1 transporter is found in glial cells.

GLUT1 is expressed on both membranes of the endothelial cells, but asymmetrically in that more immunogold staining is found on the ablumenal membrane in the rat 
(Farrell \& Pardridge, 1991), mouse (Kawamoto et al. 1995) and the rabbit (Cornford et al. 1993). This asymmetric distribution of transporter may aid the unidirectional movement of glucose. The distribution may vary between species (the transporter appears to be equally distributed between membranes in human capillaries (Gerhart et al. 1989)) and may be subject to regulation (Cornford et al. 1994). Further study of the distribution of transporter may give further insight into the control of glucose transport in the brain.

Other barrier tissues in the central nervous system do show a different distribution of transporters. In the choroid plexus, the transporter is found in the basolateral membrane only (Harik et al. 1990; Farrell et al. 1992), whilst the ependymal lining of the ventricle has transporter only at the apical membrane (Farrell et al. 1992). The activity of glucose transporters may be regulated by their degree of glycosylation; the protein in endothelial cells migrates with a $\mathrm{M}_{\mathrm{r}}$ of 54000 , whilst the protein in the choroid plexus is less glycosylated, with a $M_{r}$ of 47000 (Kumagai et al. 1994) and the deglycosylated protein has a $M_{r}$ of 42000 . Deglycosylation decreases the affinity of glucose transport and increases the amount of transporter in the cytoplasmic compartment (Asano et al. 1991, 1993), raising the possibility that glycosylation is part of the regulatory process for GLUT1 transporters.

GLUT3 has been detected in the brains of several species as a protein of $45-50 \mathrm{kDa}$ (Mantych et al. 1992; Nagamatsu et al. 1992, 1993; Vannucci et al. 1994), or as 3.5-4.1 kb transcripts of the mRNA (Kayano et al. 1988; Yano et al. 1991; Nagamatsu et al. 1992, 1993). The transporter was specifically located in the neurons and absent from blood vessels in the rat (Maher et al. 1993). However, immunocytochemistry and Western blotting of human and dog tissue revealed GLUT3 in microvessels as well as neurons (Gerhart et al. 1992; Mantych et al. 1992). Recently, the presence of GLUT3 in brain microvessels in dog, but not rat, has been confirmed using antibodies specific for the carboxyl terminal ends of the sequences for each species (Gerhart et al. 1995), suggesting that the dog may be a better model than other species for glucose transport in the human brain. This report also confirmed that GLUT3 is found in the nerve fibres rather than in the cell bodies, in contrast to the distribution of the GLUT3 mRNA, which is found in the cell bodies (Nagamatsu et al. 1992). GLUT3 is not expressed in normal glial cells (Gerhart et al. 1992; Nagamatsu et al. 1993), although GLUT3 expression does occur in gliomas (Boado et al. 1994). GLUT5 (considered to be a fructose transporter in the intestine) has been found in the microvessels (Mantych et al. 1993) and microglia (Simpson et al. 1994b), but its role in the brain in unknown.

Glucose metabolism in the brain has long been considered not to be sensitive to insulin (Lund-Andersen, 1979). As expected, the insulin-sensitive transporter, GLUT4, was not detected in homogenates of whole brain (Sadiq et al. 1990). GLUT2, the low-affinity transporter of the liver and pancreas, also has not been found in whole brain (Thorens et al. 1988). The possibility of GLUT2 or GLUT4 being involved in glucose sensors of the brain will be discussed later (p. 215).

The circumventricular organs are areas of the brain which do not have a blood-brain barrier (Bouchaud \& Bosler, 1986) and are thought to integrate humoral, hormonal and neural information. At least some of these areas are known not to contain glucose transporters. Thus, no GLUT1 was found in the median eminence of the hypothalamus and the area postrema (Young \& Wang, 1990; Dermietzel et al. 1992). Also, no glucose transporter was reported in the area postrema of the human brain (Kalaria et al. 1988). 


\section{CHARACTERISTICS OF BRAIN GLUCOSE TRANSPORTERS}

Unlike some peripheral tissues, in which glucose transport into the cell limits the rate of metabolism, phosphorylation by hexokinase $(E C 2.7 .1 .1)$ is the rate-limiting step in the brain (Lund-Andersen, 1979; Furler et al. 1991); thus, the blood-brain barrier has an efficient glucose carrier. This is of relatively high affinity (the affinity constant for glucose entry is 2-7 mM; Lund-Andersen, 1979). $K_{m}$ values for glucose transporters expressed in Xenopus oocytes, have been found as equilibrium values for the non-metabolizable 3-O-methyl glucose or entry values for 2-deoxyglucose which, although nonmetabolized, is continuously removed from the interstitial space by phosphorylation. The $K_{m}$ for GLUT1-4, expressed in Xenopus oocytes, for 3-O-methyl glucose are 20.9, $42.3,10.6$ and $1.8 \mathrm{~mm}$ respectively; corresponding entry values for 2 -deoxyglucose $(6.9$, $11.2,1.4 \mathrm{mM}$ and not detectable) are somewhat lower (Gould \& Holman, 1993). Although these values indicate that glucose supply may not be entirely independent of plasma concentration (the $K_{m}$ for GLUT1 is not well below the plasma glucose concentration), the low $K_{m}$ for GLUT3, which is less than the interstitial glucose concentration of the brain of approximately $2 \mathrm{mM}$ (Lund-Andersen, 1979), should ensure an adequate and preferential supply of glucose to the neurons (glia have GLUT1 and not GLUT3). The $K_{m}$ values for GLUT2 and 4 are of interest in relation to their putative function in glucose-sensing mechanisms in the brain (see p. 215).

\section{GLUCOSE TRANSPORT IN THE DEVELOPING BRAIN}

During gestation, large changes in both the distribution and the amounts of GLUT1 and GLUT3 occur in the brain, while in the neonate, the brain utilizes ketone bodies and is less dependent on glucose than at other times. These changes in the developing brain may give insight into the relationships between brain development and biochemical function. Large amounts of glucose are required for glycolysis in the avascular embryonic brain (about day 12 of gestation). Both GLUT1 (mainly $53 \mathrm{kDa}$ ) protein (Dermietzel et al. 1992) and GLUT1 mRNA (Bondy et al. 1992) are high at this stage, GLUT1 levels being twice those found in the adult (Matsumoto et al. 1995). When cerebral microvessels start to appear and closure of the blood-brain barrier occurs, there is a considerable reduction in GLUT1 expression in the neuroepithelial cells. The $43 \mathrm{kDa}$ form of the transporter remains in brain parenchyma. At the same time, the expression of the gene is considerably reduced. As the brain matures postnatally, glucose metabolism increases and consequently the expression of GLUT1 and its mRNA increases, particularly in parenchymal cells characteristic of glia (Bondy et al. 1992). Thus, in the rat, GLUT1 expression is at adult levels by gestational day 19, falling at birth, particularly in the $50 \mathrm{kDa}$ band, and progressively increases again (Sivitz et al. 1989). In the rabbit, GLUT1 decreases to a minimum at $10 \mathrm{~d}$ gestation before increasing again (Sadiq et al. 1990), perhaps indicating that ketone bodies are contributing to brain metabolism. GLUT1 mRNA, unlike GLUT1 protein, does not decrease after birth in the rabbit, suggesting that down-regulation might be post-transcriptional (Dwyer \& Pardridge, 1993).

In contrast to GLUT1, GLUT3 appears as neurons mature and become functional. GLUT3 is not present in the neuropil in the newborn human infant (Mantych et al. 1992) and increases progressively after birth, as neuronal maturation occurs. In the rat, GLUT3 increases progressively throughout the postnatal period, so that nearly adult levels are reached by weaning (Vannucci et al. 1994). This pattern is also seen by in situ 
hybridization. GLUT3 mRNA is low throughout most of gestation, but increases progressively after birth, being predominately expressed in the grey matter (Bondy et al. 1992).

\section{PHYSIOLOGICAL REGULATION OF BRAIN GLUCOSE TRANSPORTERS}

The brain requires a constant glucose supply which does not vary with the blood glucose concentration. This is brought about primarily by glucose metabolism itself being the rate-limiting step. Transport does have some influence in that it is thought to be rate limiting at very low glucose concentrations (Robinson \& Rapaport, 1986); at high glucose concentrations carrier-mediated glucose transport is down-regulated (Gjedde \& Crone, 1981). The $K_{m}$ of GLUT1 is not sufficiently low to ensure no fluctuation of glucose supply to the brain with the glycaemic state and some change in expression of glucose transporters might be expected. GLUT1 is down-regulated by the hyperglycaemia seen in streptozotocin diabetes (Pardridge et al. 1990b); however, GLUT1 mRNA is increased (Choi et al. 1989), suggesting that regulation of GLUT1 protein is post-transcriptional in this instance. However, streptozotocin diabetes does not always result in any changes in GLUT1 or GLUT3 mRNA (Nagamatsu et al. 1994). The responses might vary, depending on the degree of hyperglycaemia. Hypoglycaemia produced by a prolonged fast in mice increased GLUT1 and GLUT3 mRNA levels in the brain, but did not alter the amounts of GLUT proteins (Nagamatsu et al. 1994).

Exposure to cold causes sympathetic stimulation, resulting in increased energy metabolism and, hence, heat production. Cold exposure for $2 \mathrm{~h}$ at $4^{\circ}$ increased GLUT1 and GLUT3 mRNA levels in mouse brain. In both lean and obsese Zucker rats cold exposure for $2 \mathrm{~h}$ also increased GLUT1. The effect was greatest in the frontal cortex, hippocampus, thalamus and cerebellum (Rayner et al. 1994a), which are known to respond to sensory or emotional stimuli.

Physiological challenges which may alter the glycaemic state clearly affect glucosetransporter expression in the brain under some circumstances. As might be expected from the physiology of blood-brain glucose transfer, the changes are subtle rather than overwhelming. This will make elucidation of the controlling mechanisms more difficult.

\section{GLUCOSE TRANSPORTERS IN DISEASE}

Glucose-transporter expression is altered in various disease states and may be related to altered glucose metabolism. In Alzheimer's disease, glucose metabolism is decreased and is associated with decreased amounts of GLUT1 protein in cerebral microvessels in the frontal cortex and hippocampus, the regions most affected (Kalaria \& Harik, 1989). GLUT3 levels also seem to be decreased in the cortex and change relative to the synaptic protein SP14 (Simpson et al. 1994a). GLUT3 is not merely decreased by the loss of synapses, but may reflect a loss of metabolic activity in cell bodies following the destruction of their afferent input (Harr et al. 1995).

In Huntington's disease, there is neural degeneration of the basal ganglia. GLUT1 as well as GLUT3 are decreased in the caudate, presumably because of the decline in glucose metabolism following the destruction of the neurons (Gamberino \& Brennan, 1994). Glucose transport also seems to be down-regulated during cerebral ischaemia (Suzuki et al. 1994), while expression of GLUT1 mRNA is increased in glia and neurons 
(Lee \& Bondy, 1993). However, brain dysfunction does not always lead to downregulation of transporters. GLUT1 is a stress-inducible protein (Baldwin, 1993) and, therefore, it is not surprising that GLUT1 mRNA and protein increase in response to burn injury, with only minor changes in GLUT3 (Gamelli et al. 1994).

Brain tumours often have increased glucose utilization. However, this does not necessarily imply increased glucose transporter levels, as their capillaries lack tight junctions and have increased permeability to glucose. GLUT1 was absent in most gliomas and also in metastatic brain tumours (Guerin et al. 1990), which showed high vascular permeability, but astrocytic tumours were positive for GLUT1. Dexamethazone-treated gliomas in the rat show decreased tumour growth, decreased vascular density and increased expression of GLUT1 (Guerin et al. 1992). The expression of glucose transporters may be a useful independent marker of tumour development and may lead to an understanding of the factors relating the integrity of the blood-brain barrier and brain metabolism.

\section{BRAIN GLUCOSE TRANSPORTERS AS GLUCOSE SENSORS}

The sensing of glucose concentrations has long been thought to be involved in the control of voluntary food intake (Mayer, 1953). In this glucostatic theory, glucose utilization must somehow be sensed in the brain, and/or information relayed to the brain from the periphery. Glucose-sensitive neurons have been found at two sites in the brain, i.e. the nucleus tractus solitarius and the hypothalamus; glucose injections into the hypothalamus can reduce food intake while destruction of the ventromedial hypothalamus increases intake and causes obesity (Young, 1981).

It is likely that glucose transporters are involved in these signalling systems. Although it is possible that the normal brain glucose transporters function in the glucose-sensing neurons, these areas might be distinguished by the presence of a distinctive glucose transporter. GLUT2 and 4 have both been suggested for this role (Widmaier, 1992). In glucose-sensitive neurons, glucose entry may be proportional to the external glucose concentration. Thus, it should function in a similar manner to GLUT2 in the pancreas and this high $K_{m}$ transporter might be expected to be present in the brain (Widmaier, 1992). Results on the brain distribution of GLUT2 have varied from finding GLUT2 protein by Western blotting in all major brain regions (Brant et al. 1993) to a failure to demonstrate this isoform either as the protein or its mRNA (Rayner et al. 1994b). Recently, the distribution of GLUT2 mRNA in discrete brain regions which are known to be glucose sensitive has been investigated (Leloup et al. 1994). GLUT2 mRNA was demonstrated in a range of brain nuclei, known to be glucose sensitive, including the lateral hypothalamic area and arcuate nucleus. However, given the sensitivity of the technique used (polymerase chain reaction), only low-level signals were obtained, except for the motor nucleus of the vagus. No signal for GLUT2 was obtained by Western blotting from any of these areas.

An insulin-sensitive glucose receptor is required, however, to distinguish raised glucose concentrations not associated with increased arterio-venous differences from new glucose from food intake (Van Italie, 1990). Brant et al. (1993) have suggested that GLUT4 is present in the hypothalamus and this group has recently suggested that this GLUT4 might be part of a metabolic signalling system (Livingstone et al. 1995). High glucose concentrations would presumably alter the activity in hypothalamic neurons, but 
only when GLUT4 is translocated from the intracellular pool by insulin, such as will occur in the postprandial period. This hypothesis presupposes either that insulin can enter the hypothalamus, or be locally secreted in proportion to that produced at the periphery. It is worth noting that the median eminence is a circumventricular organ and, hence, is outside the blood-brain barrier. However, we could not detect GLUT4 in the hypothalamus using comparable techniques to those of Brant et al. (1993). Both GLUT4 mRNA and protein were detected in the cerebellum (Rayner et al. 1994b). We suggest that insulin-sensitive neurons in the cerebellum may form part of a system sensing glucose utilization by muscle, by integrating proprioceptor information received from the periphery with information from insulin-sensitive glucoreceptors. The cerebellum might then be a sensor for peripheral glucose utilization.

\section{CONCLUSIONS}

The study of glucose transporters in the brain gives an insight into how the brain provides for its own metabolic needs and may also indicate how it is involved in monitoring the metabolism of the rest of the body. Some of the changes occurring in glucose-transporter expression in brain development, nutritional challenge or disease are described. At present less is known about how these changes occur at the anatomical, physiological, biochemical or gene levels. The challenge for the future is to unravel these subtleties of glucose transport in the brain.

The author acknowledges funding from the Scottish Office Agricultural, Environmental and Fisheries Department.

\section{REFERENCES}

Asano, T., Katagiri, H., Takata, K., Lin, J.-L., Ishihara, H., Inukai, K., Tsukuda, K., Kikuchi, M., Hirano, H., Yazaki, Y. \& Oka, Y. (1991). The role of $N$-glycosylation of GLUT1 for glucose transport activity. Journal of Biological Chemistry 266, 2632-2636.

Asano, T., Takata, K., Katagiri, H., Ishihara, H., Inukai, K., Anai, M., Hirano, H., Yazaki, Y. \& Oka, Y. (1993). The role of N-glycosylation in the targeting and stability of GLUT1 glucose transporter. FEBS Letters 324, 258-261.

Bagley, P. R., Tucker, S. P., Nolan, C., Lindsay, J. G., Davies, A., Baldwin, S. A., Cremer, J. E. \& Cunningham, V. J. (1989). Anatomical mapping of glucose transporter protein and pyruvate dehydrogenase in rat brain: an immunogold study. Brain Research 499, 214-224.

Baldwin, S. A. (1993). Mammalian passive glucose transporters: members of an ubiquitous family of active and passive transport proteins. Biochimica et Biophysica Acta 1154, 17-49.

Birnbaum, M. J., Haspel, H. C. \& Rosen, O. M. (1986). Cloning and characterization of a cDNA encoding the rat brain glucose-transporter protein. Proceedings of the National Academy of Sciences, USA 83, 5784-5788.

Boado, R. J., Black, K. L. \& Pardridge, W. M. (1994). Gene expression of GLUT3 and GLUT1 glucose transporters in human brain tumors. Molecular Brain Research 27, 51-57.

Boado, R. J. \& Pardridge, W. M. (1990). The brain-type glucose transporter is specifically expressed at the blood-brain barrier. Biochemical and Biophysical Research Communications 166, 174-179.

Bondy, C. A., Lee, W.-H. \& Zhou, J. (1992). Ontogeny and cellular distribution of brain glucose transporter gene expression. Molecular and Cellular Neurosciences 3, 305-314.

Bouchaud, C. \& Bosler, O. (1986). The circumventricular organs of the mammalian brain with special reference to monoaminergic innervation. International Review of Cytology 105, 283-327.

Brant, A. M., Jess, T. J., Milligan, G., Brown, C. M. \& Gould, G. W. (1993). Immunological analysis of glucose transporters expressed in different regions of the rat brain and central nervous system. Biochemical and Biophysical Research Communications 192, 1297-1302. 
Choi, T. B., Boado, R. J. \& Pardridge, W. M. (1989). Blood-brain barrier glucose transporter mRNA is increased in experimental diabetes. Biochemical and Biophysical Research Communications 164, 375-380.

Cornford, E. M., Hyman, S. \& Pardridge, W. M. (1993). An electron microscopic immunogold analysis of developmental up-regulation of the blood-brain barrier GLUT1 glucose transporter. Journal of Cerebral Blood Flow and Metabolism 13, 841-854.

Cornford, E. M., Hyman, S. \& Swartz, B. E. (1994). The human brain GLUT1 glucose transporter: ultrastructural localisation to the blood-brain barrier endothelia. Journal of Cerebral Blood Flow and Metabolism 14, 106-112.

Dermietzel, R. \& Krause, D. (1991). Molecular anatomy of the blood-brain barrier as defined by immunocytochemistry. International Review of Cytology 127, 57-109.

Dermietzel, R., Krause, D., Kremer, M., Wang, C. \& Stevenson, B. (1992). Pattern of glucose transporter (Glut 1) expression in embryonic brains is related to maturation of blood-brain barrier tightness. Developmental Dynamics 193, 152-163.

Dick, A. P. K., Harik, S. I., Klip, A. \& Walker, D. M. (1984). Identification and characterization of the glucose transporter of the blood-brain barrier by cytochalasin B binding and immunological reactivity. Proceedings of the National Academy of Sciences, USA 81, 7233-7237.

Dwyer, K. J. \& Pardridge, W. M. (1993). Developmental modulation of blood-brain barrier and choroid plexus GLUT1 glucose transporter messenger ribonucleic acid and immunoreactive protein in rabbits. Endocrinology 132, 558-565.

Farrell, C. L. \& Pardridge, W. M. (1991). Blood-brain barrier glucose transporter is asymmetrically distributed on brain capillary endothelial lumenal and ablumenal membranes: an electron microscopic immunogold study. Proceedings of the National Academy of Sciences, USA 88, 5779-5783.

Farrell, C. L., Yang, J. \& Pardridge, W. M. (1992). Glut-1 glucose transporter is present within apical and basolateral membranes of brain epithelial interfaces and in microvascular endothelia with and without tight junctions. Journal of Histochemistry and Cytochemistry 40, 193-199.

Flier, J. S., Mueckler, M., McCall, A. L. \& Lodish, H. F. (1987). Distribution of glucose transporter messenger RNA transcripts in tissues of rat and man. Journal of Clinical Investigation 79, 657-661.

Furler, S. M., Jenkins, A. B., Storlien, L. H. \& Kraegen, E. W. (1991). In vivo location of the rate limiting step of hexose uptake in muscle and brain tissue of rats. American Journal of Physiology 261, E337-E347.

Gamberino, W. C. \& Brennan, W. A. Jr (1994). Glucose transporter isoform expression in Huntington's disease brain. Journal of Neurochemistry 63, 1392-1397.

Gamelli, R. L., Liu, H., He, L.-K. \& Hofmann, C. A. (1994). Alterations of glucose transporter mRNA and protein levels in brain following thermal injury and sepsis in mice. Shock 1, 395-400.

Gerhart, D. Z., Broderius, M. A., Borson, N. D. \& Drewes, L. R. (1992). Neurons and microvessels express the brain glucose transporter protein GLUT 3. Proceedings of the National Academy of Sciences, USA 89, 733-737.

Gerhart, D. Z., Leino, R. L., Borson, N. D., Taylor, W. E., Gronlund, K. M., McCall, A. L. \& Drewes, L. R. (1995). Localisation of glucose transporter GLUT3 in brain: comparison of rodent and dog using species-specific carboxyl-terminal antisera. Neuroscience 66, 237-246.

Gerhart, D. Z., LeVasseur, R. J., Broderius, M. A. \& Drewes, L. R. (1989). Glucose localization in brain using light and electron immunochemistry. Journal of Neuroscience Research 22, 464-472.

Gjedde, A. \& Crone, C. (1981). Blood-brain glucose transfer: repression in chronic hyperglycaemia. Science 214, 456-457.

Gould, G. W. \& Holman, G. D. (1993). The glucose transporter family: structure, function and tissue-specific expression. Biochemical Journal 295, 329-341.

Guerin, C., Laterra, J., Hruban, R. H., Brem, H., Drewes, L. R. \& Goldstein, G. W. (1990). The glucose transporter and blood-brain barrier of human brain tumors. Annals of Neurology 28, 758-765.

Guerin, C., Wolff, J. E. A., Laterra, J., Drewes, L. R., Brem, H. \& Goldstein, G. W. (1992). Vascular differentiation and glucose transporter expression in rat gliomas: effects of steroids. Annals of Neurology 31, 481-487.

Harik, S. I., Kalaria, R. N., Andersson, L., Lundahl, P. \& Perry, G. (1990). Immunocytochemical localization of the erythroid glucose transporter: abundance in tissues with barrier functions. Journal of Neuroscience 10, 3862-3872.

Harr, S. D., Simonian, N. A. \& Hyman, B. T. (1995). Functional alterations in Alzheimer's disease: decreased glucose transporter 3 immunoreactivity in the perforant pathway terminal zone. Journal of Neuropathology and Experimental Neurology 54, 38-41. 
James, D. E., Strube, M. \& Mueckler, M. (1989). Molecular cloning and characterization of an insulinregulatable glucose transporter. Nature 338, 83-87.

Kalaria, R. N., Gravina, S. A., Schmidley, J. W., Perry, G. \& Harik, S. I. (1988). Glucose transporter of the human brain and blood-brain barrier. Annals of Neurology 24, 757-764.

Kalaria, R. N. \& Harik, S. I. (1989). Reduced glucose transporter at the blood-brain barrier and in the brain in Alzheimer's disease. Journal of Neurochemistry 53, 1083-1088.

Kasanicki, M. A., Cairns, M. T., Davies, A., Gardiner, R. M. \& Baldwin, S. A. (1987). Identification and characterization of the glucose-transport protein of the bovine blood/brain barrier. Biochemical Journal 247, 101-108.

Kasanicki, M. A., Jessen, K. R., Baldwin, S. A., Boyle, J. M., Davies, A. \& Gardiner, R. M. (1989). Immunocytochemical localisation of the glucose-transport protein in mammalian brain capillaries. Histochemical Journal 21, 47-51.

Kawamoto, S., Goto, H., Watanabe, M. \& Shimada, M. (1995). GLUT-1 glucose transporter is localized heterogenously within the microvessels of the mouse hippocampus. Acta Histochemica 97, 105-111.

Kayano, T., Fukumoto, H., Eddy, R. L., Fan, Y.-S., Byers, M. G., Shows, T. B. \& Bell, G. I. (1988). Evidence for a family of human glucose transporter-like proteins. Sequence and gene localization of a protein expressed in fetal, skeletal muscle and other tissues. Journal of Biological Chemistry 263, $15245-15248$.

Kumagai, A. K., Dwyer, K. J. \& Pardridge, W. M. (1994). Differential glycosylation of the GLUT1 glucose transporter in brain capillaries and choroid plexus. Biochimica et Biophysica Acta 1193, 24-30.

Lee, W.-H. \& Bondy, C. A. (1993). Ischemic injury induces brain glucose transporter gene expression. Endocrinology 133, 2540-2544.

Leloup, C., Arluison, M., Lepetit, N., Cartier, N., Marfaing-Jallat, P., Ferré, P. \& Pénicaud, L. (1994). Glucose transporter 2 (GLUT 2) - expression in specific brain nuclei. Brain Research 638, 221-226.

Livingstone, C., Lyall, H. \& Gould, G. W. (1995). Hypothalamic GLUT4 expression: a glucose- and insulin-sensing mechanism? Molecular and Cellular Endocrinology 107, 67-70.

Lund-Andersen, H. (1979). Transport of glucose from blood to brain. Physiological Reviews 59, 305-352.

Maher, F., Vanmucci, S. I. \& Simpson, I. A. (1993). Glucose transporter isoforms in brain: absence of GLUT3 from the blood-brain barrier. Journal of Cerebral Blood Flow and Metabolism 13, 342-345.

Maher, F., Vannucci, S. J. \& Simpson, I. A. (1994). Glucose transporter proteins in brain. FASEB Journal 8, 1003-1011.

Mantych, G. J., James, D. E., Chung, H. D. \& Devaskar, S. U. (1992). Cellular localization and characterization of Glut-3 transporter isoform in human brain. Endocrinology 131, 1270-1278.

Mantych, G. J., James, D. E., Chung, H. D. \& Devaskar, S. U. (1993). Jejunal/kidney glucose transporter isoform (Glut-5) is expressed in the human blood-brain barrier. Endocrinology 132, 35-40.

Matsumoto, K., Akazawa, S., Ishibashi, M., Trocino, R. A., Matsuo, H., Yamasaki, H., Yamaguchi, Y., Nagamatsu, S. \& Nagataki, S. (1995). Abundant expression of GLUT1 and GLUT3 in rat embryo during the early organogenesis period. Biochemical and Biophysical Research Communications 209, 95-102.

Mayer, J. (1953). Glucostatic mechanism of regulation of food intake. New England Journal of Medicine 249, 13-16.

Morgello, S., Uson, R. R., Schwartz, E. J. \& Haber, R. S. (1995). The human blood-brain barrier glucose transporter (GLUT1) is a glucose transporter of gray matter astrocytes. Glia 14, 43-54.

Nagamatsu, S., Kornhauser, J. M., Burant, C. F., Seino, S., Mayo, K. E. \& Bell, G. I. (1992). Glucose transporter expression in brain cDNA sequence of mouse GLUT3, the brain facilitative isoform, and identification of sites of expression by in situ hybridisation. Journal of Biological Chemistry 267, 467-472.

Nagamatsu, S., Sawa, H., Inoue, N., Nakamichi, Y., Takeshima, H. \& Hoshino, T. (1994). Gene expression of GLUT3 glucose transporter regulated by glucose in vivo in mouse brain and in vitro in neuronal cell cultures from rat embryos. Biochemical Joumal 300, 125-131.

Nagamatsu, S., Sawa, H., Kamada, K., Nakamichi, Y., Yoshimoto, K. \& Hoshino, T. (1993). Neuron-specific glucose transporter (NSGT): CNS distribution of GLUT3 rat glucose transporter (RGT3) in rat central neurons. FEBS Letters 334, 289-295.

Nishizaki, T., Kammesheidt, A., Suminkawa, K., Asada, T. \& Okada, Y. (1995), A sodium- and energy-dependent glucose transporter with similarities to SGLT1-2 is expressed in bovine cortical vessels. Neuroscience Research 22, 13-22.

Pardridge, W. M. \& Boado, R. J. (1993). Molecular cloning and regulation of gene expression of blood-brain barrier glucose transporter. In The Blood-Brain Barrier Cellular and Molecular Biology, pp. 395-440 [W. M. Pardridge, editor]. New York: Raven Press. 
Pardridge, W. M., Boado, R. J. \& Farrell, C. R. (1990a). Brain-type glucose transporter (GLUT-1) is selectively localized to the blood-brain barrier. Journal of Biological Chemistry 265, 18035-18040.

Pardridge, W. M. \& Oldendorf, W. H. (1975). Kinetics of blood-brain barrier transport of hexoses. Biochimica et Biophysica Acta 382, 377-392.

Pardridge, W. M., Triguero, D. \& Farrell, C. R. (1990b). Downregulation of blood-brain barrier glucose transporter in experimental diabetes. Diabetes 39, 1040-1044.

Rayner, D. V., Thomas, M. E. A. \& Trayhurn, P. (1994a). GLUT1 mRNA in brain regions of lean and obese Zucker $(\mathrm{fa} / \mathrm{fa}$ ) rats acutely exposed to cold. Journal of Physiology 481, 28P-29P.

Rayner, D. V., Thomas, M. E. A. \& Trayhurn, P. (1994b). Glucose transporters (GLUTs 1-4) and their mRNAs in regions of the rat brain: insulin-sensitive transporter expression in the cerebellum. Canadian Journal of Physiology and Pharmacology 72, 476-479.

Robinson, P. J. \& Rapaport, S. I. (1986). Glucose transport and metabolism in the brain. American Journal of Physiology 250, R127-R136.

Sadiq, F., Holtzclaw, L., Chundu, K., Muzzfar, A. \& Devaskar, S. (1990). The ontogeny of the rabbit brain glucose transporter. Endocrinology 126, 2417-2424.

Simpson, I. A., Chundu, K. R., Davies-Hill, T., Honer, W. G. \& Davies, P. (1994a). Decreased concentrations of GLUT1 and GLUT3 glucose transporters in the brains of patients with Alzheimer's disease. Annals of Neurology 35, 546-551.

Simpson, I. A., Vannucci, S. J. \& Maher, F. (1994b). Glucose transporters in mammalian brain. Biochemical Society Transactions 22, 671-675.

Sivitz, W., DeSautel, S., Walker, P. S. \& Pessin, J. E. (1989). Regulation of the glucose transporter in developing rat brain. Endocrinology 124, 1875-1880.

Sokoloff, L. (1973). Metabolism of ketone bodies by the brain. Annual Review of Medicine 24, 271-280.

Suzuki, H., Nagashima, T., Fujita, K., Tamaki, N., Sugioka, K., Yamadori, T. \& Yamaguchi, M. (1994). Cerebral ischemia alters glucose transporter kinetics across rat brain microvascular endothelium Quantitative analysis by an in situ brain perfusion method. Journal of the Autonomic Nervous System 49 , S173-S176.

Thorens, B., Sarkar, H. K., Kaback, H. R. \& Lodish, H. (1988). Cloning and functional expression in bacteria of a novel glucose transporter present in liver, intestine, kidney, and $\beta$-pancreatic islet cells. Cell 55, $281-290$.

Van Italie, T. B. (1990). The glucostatic theory 1953-1988: roots and branches. International Journal of Obesity 14, Suppl. 3, 1-10.

Vannucci, S. J., Seaman, L. B., Brucklacher, R. M. \& Vannucci, R. C. (1994). Glucose transport in developing rat brain: glucose transporter proteins, rate constants and cerebral glucose utilisation. Molecular and Cellular Biochemistry 140, 177-184.

Widmaier, E. P. (1992). Metabolic feedback in mammalian endocrine systems. Hormonal and Metabolic Research 24, 147-153.

Yano, H., Seino, Y., Inagaki, N., Hiniokio, Y., Yamamoto, T., Yasuda, K., Masuda, K., Someya, Y. \& Imura, H. (1991). Tissue distribution and species difference of the brain type glucose transporter (GLUT3). Biochemical and Biophysical Research Communications 174, 470-477.

Young, J. K. (1981). Current evidence for a role of glucose as a regulator of hypothalamic function and caloric homeostasis. Psychoneuroendocrinology 6, 281-299.

Young, J. K. \& Wang, C. (1990). Glucose transporter immunoreactivity in the hypothalamus and area postrema. Brain Research Bulletin 24, 525-528. 